\title{
Front Matter: Volume 10776
}

, "Front Matter: Volume 10776," Proc. SPIE 10776, Remote Sensing of the Atmosphere, Clouds, and Precipitation VII, 1077601 (27 November 2018); doi: $10.1117 / 12.2520628$

Event: SPIE Asia-Pacific Remote Sensing, 2018, Honolulu, Hawaii, United SPIE. States 


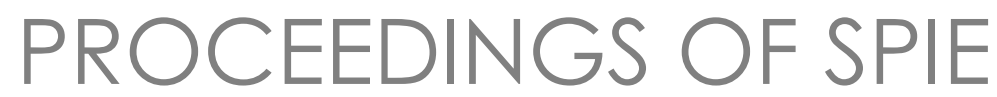

\title{
Remote Sensing of the Atmosphere, Clouds, and Precipitation VII
}

\author{
Eastwood Im \\ Song Yang \\ Editors
}

\section{4-26 September 2018}

Honolulu, Hawaii, United States

Sponsored by

SPIE

Cosponsored by

NASA-National Aeronautics and Space Administration (United States)

RADI-Institute of Remote Sensing and Digital Earth, Chinese Academy of Sciences (China)

State Key Laboratory of Remote Sensing Science, Chinese Academy of Sciences (China)

Ministry of Earth Sciences (India)

\section{Cooperating Organizations}

University of Hawai'i at Mānoa (United States)

JAXA-Japan Aerospace Exploration Agency (Japan)

NICT-National Institute of Information and Communications Technology (Japan)

ISRO-Indian Space Research Organization (India)

ESSO_Earth System Science Organization (India)

Published by

SPIE 
The papers in this volume were part of the technical conference cited on the cover and title page. Papers were selected and subject to review by the editors and conference program committee. Some conference presentations may not be available for publication. Additional papers and presentation recordings may be available online in the SPIE Digital Library at SPIEDigitalLibrary.org.

The papers reflect the work and thoughts of the authors and are published herein as submitted. The publisher is not responsible for the validity of the information or for any outcomes resulting from reliance thereon.

Please use the following format to cite material from these proceedings:

Author(s), "Title of Paper," in Remote Sensing of the Atmosphere, Clouds, and Precipitation VII, edited by Eastwood Im, Song Yang, Proceedings of SPIE Vol. 10776 (SPIE, Bellingham, WA, 2018) Seven-digit Article CID Number.

ISSN: 0277-786X

ISSN: 1996-756X (electronic)

ISBN: 9781510621275

ISBN: 9781510621282 (electronic)

Published by

SPIE

P.O. Box 10, Bellingham, Washington 98227-0010 USA

Telephone +1 3606763290 (Pacific Time) · Fax +1 3606471445

SPIE.org

Copyright (C) 2018, Society of Photo-Optical Instrumentation Engineers.

Copying of material in this book for internal or personal use, or for the internal or personal use of specific clients, beyond the fair use provisions granted by the U.S. Copyright Law is authorized by SPIE subject to payment of copying fees. The Transactional Reporting Service base fee for this volume is $\$ 18.00$ per article (or portion thereof), which should be paid directly to the Copyright Clearance Center (CCC), 222 Rosewood Drive, Danvers, MA 01923. Payment may also be made electronically through CCC Online at copyright.com. Other copying for republication, resale, advertising or promotion, or any form of systematic or multiple reproduction of any material in this book is prohibited except with permission in writing from the publisher. The CCC fee code is 0277$786 \mathrm{X} / 18 / \$ 18.00$.

Printed in the United States of America.

Publication of record for individual papers is online in the SPIE Digital Library.

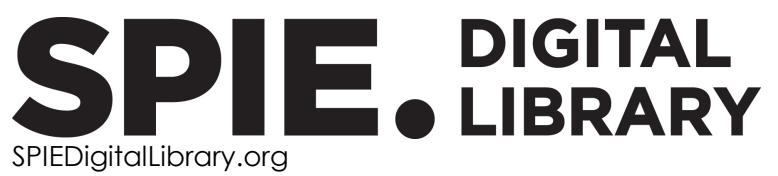

Paper Numbering: Proceedings of SPIE follow an e-First publication model. A unique citation identifier (CID) number is assigned to each article at the time of publication. Utilization of CIDs allows articles to be fully citable as soon as they are published online, and connects the same identifier to all online and print versions of the publication. SPIE uses a seven-digit CID article numbering system structured as follows:

- The first five digits correspond to the SPIE volume number.

- The last two digits indicate publication order within the volume using a Base 36 numbering system employing both numerals and letters. These two-number sets start with $00,01,02,03,04$, 05, 06, 07, 08, 09, 0A, OB ... 0Z, followed by 10-1Z, 20-2Z, etc. The CID Number appears on each page of the manuscript. 


\title{
Contents
}

\author{
vii Authors \\ ix Symposium Committees \\ xi Conference Committee
}

REMOTE SENSING OF CLOUDS AND PRECIPITATION

1077602 Current status of the Dual-frequency precipitation Radar on the Global Precipitation Measurement core spacecraft and scan pattern change test operations results (Invited Paper) [10776-1]

REMOTE SENSING OF AEROSOLS AND DUST

1077607 Synergistic use of next-generation geostationary and polar orbit satellites for investigating aerosols, clouds, and radiation [10776-6]

\section{EMERGING TECHNOLOGIES FOR ATMOSPHERIC REMOTE SENSING I}

10776 OD Compact Midwave Imaging System (CMIS) for retrieval of cloud motion vectors and cloud geometric heights [10776-12]

10776 OE Benefits of a quadrature Mach Zehnder interferometer as demonstrated in the Optical Autocovariance Wind and Lidar (OAWL) wind and aerosol measurements [10776-13]

\section{REMOTE SENSING OF CYCLONES AND SEVERE STORMS}

$107760 \mathrm{G}$ Observing fast mesoscale atmospheric processes with a geostationary microwave sounder [10776-16] 
EMERGING TECHNOLOGIES FOR ATMOSPHERIC REMOTE SENSING II

10776 Ol Atmospheric remote sensing with convoys of miniature radars (Invited Paper) [10776-21]

10776 0J All-weather microwave atmospheric sensing using CubeSats and constellations (Invited Paper) [10776-22]

ALGORITHM AND VALIDATION OF AEROSOLS, CLOUDS, CONVECTION, AND PRECIPITATION

10776 OQ Possible improvement of the GPM's Dual-frequency Precipitation Radar (DPR) algorithm (Invited Paper) [10776-29]

10776 OR The EarthCARE Cloud Profiling Radar (CPR) doppler measurements in deep convection: challenges, post-processing, and science applications [10776-30]

10776 OT Evaluation of the validation of TRMM data over the region of Qilianshan mountains in Northwest China [10776-32]

REMOTE SENSING OF EXTREME WEATHER AND EVENTS

10776 OW Summer ozone variation derived from FY3/TOU satellite data and impacts of East Asian summer monsoon [10776-42]

10776 OX Climate change and its impact on drought in Eastern Gansu rainfed agricultural area in Northwest China in the last thirty years [10776-37]

\section{REMOTE SENSING OF ATMOSPHERIC CHEMISTRY AND GREENHOUSE GASES}

$1077602 \quad$ Clouds effect on the atmospheric total column carbon dioxide retrieval by space orbiting Argus 1000 micro-spectrometer: introductory study [10776-39]

REGIONAL STUDIES OF AEROSOLS, CLOUDS, CONVECTION, AND PRECIPITATION

1077611 Study on vertical visibility during haze in Shanghai based on the spaceborne lidar [10776-45]

iv 


\section{POSTER SESSION}

1077614 Impact study on the accuracy of Global Satellite Mapping of Precipitation (GSMaP) caused by future small precipitation radar constellation [10776-49]

$1077615 \quad$ Impacts of the Kuroshio intrusion entering the Luzon Strait on the local atmosphere by satellite observations [10776-50]

1077616 Discrimination and retrieval of aerosol types using multi-channels including near-UV and polarization by GCOM-C/SGLI [10776-52]

1077617 The fact and causes of warm-dry and warm-wet change since 1971 in HEXI corridor area of Gansu Province, China [10776-54]

1077619 Application of dust and PM2.5 detection methods using MODIS data to the Asian dust events which aggravated respiratory symptoms in Western Japan in May 2011 [10776-57]

$107761 \mathrm{~A} \quad$ Application of atmospheric low-frequency oscillation on meteorological drought forecast in Eastern part of the Northwest China [10776-58] 
Proc. of SPIE Vol. 10776 1077601-6

Downloaded From: https://www.spiedigitallibrary.org/conference-proceedings-of-spie on 26 Apr 2023 Terms of Use: https://www.spiedigitallibrary.org/terms-of-use 


\section{Authors}

Numbers in the index correspond to the last two digits of the seven-digit citation identifier (CID) article numbering system used in Proceedings of SPIE. The first five digits reflect the volume number. Base 36 numbering is employed for the last two digits and indicates the order of articles within the volume. Numbers start with 00, 01, 02, 03, 04, 05, 06, 07, 08, 09, OA, OB...0Z, followed by 10-1Z, 20-2Z, etc.

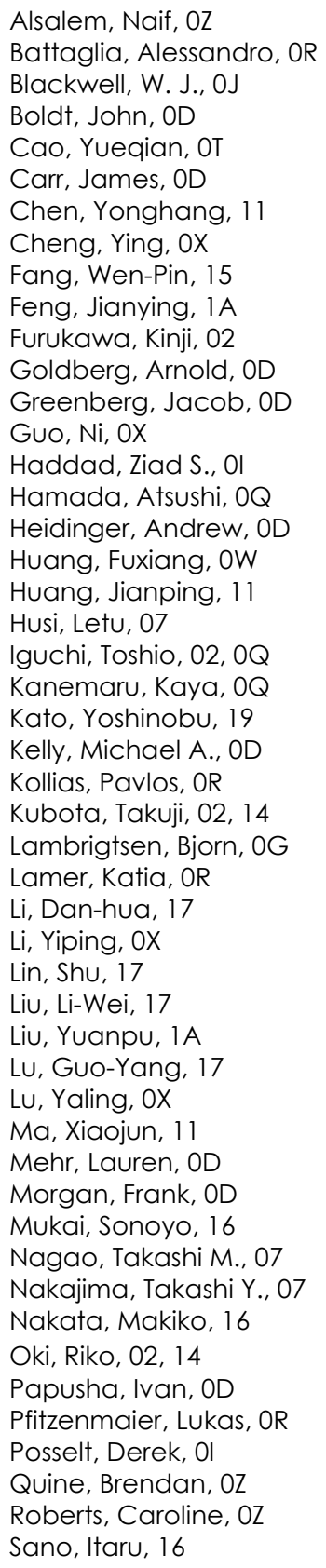

\author{
Sha, Sha, OX \\ Stephens, Graeme L., 이 \\ Sy, Ousmane O., 01 \\ Takenaka, Hideaki, 07 \\ Tang, Shihao, OW \\ Tatarevic, Alexandra, OR \\ Tridon, Frederic, OR \\ Tsouvaltsidis, Catherine, $\mathrm{OZ}$ \\ Tucker, S., OE \\ van den Heever, Sue C., 이 \\ Wang, Weihe, OW \\ Wang, Zhilan, $1 \mathrm{~A}$ \\ Wei, Wang, OX \\ Weimer, C., OE \\ Weng, Min-Chuan, 15 \\ Wilson, John, OD \\ Wu, Dong, OD \\ Yamaji, Moeka, 14 \\ Yamamoto, Kosuke, 02 \\ Yang, Chenyi, OT \\ Yee, Sam, OD \\ Zhang, Wu, OT \\ Zhang, Yan, OW \\ Zhao, Liang, OW \\ Zhao, Qingyun, OT \\ Zheng, Jie, OX \\ Zheng, Zhe-Wen, 15
}


Proc. of SPIE Vol. 10776 1077601-8

Downloaded From: https://www.spiedigitallibrary.org/conference-proceedings-of-spie on 26 Apr 2023 Terms of Use: https://www.spiedigitallibrary.org/terms-of-use 


\title{
Symposium Committees
}

\author{
Symposium Chair
}

Upendra Singh, NASA Langley Research Center (United States)

Symposium Co-chairs

Toshiyoshi Kimura, Japan Aerospace Exploration Agency (Japan)

K. J. Ramesh, Ministry of Earth Sciences (India)

Jiancheng Shi, Institute of Remote Sensing and Digital Earth (China)

Honorary Symposium Chairs

Huadong Guo, Institute of Remote Sensing and Digital Earth (China)

Stephen Jurczyk, National Aeronautics and Space Administration (United States)

A. S. Kiran Kumar, Indian Space Research Organisation (India)

Jean-Yves Le Gall, Centre National d'Études Spatiales (France)

Robert M. Lightfoot, Jr., National Aeronautics and Space

Administration (United States)

Madhavan N. Rajeevan, Ministry of Earth Sciences (India)

Alain Ratier, EUMETSAT (Germany)

Hiroshi Yamakawa, Japan Aerospace Exploration Agency (Japan)

Symposium International Organizing Committee

Michael H. Freilich, Chair, National Aeronautics and Space Administration (United States)

Jack A. Kaye, National Aeronautics and Space Administration (United States)

Barry L. Lefer, National Aeronautics and Space Administration (United States)

Clayton P. Turner, NASA Langley Research Center (United States)

Pamela Millar, NASA Goddard Space Flight Center (United States)

David F. Young, NASA Langley Research Center (United States)

Tapsan Misra, Indian Space Research Organisation (India)

Kazuo Tachi, Japan Aerospace Exploration Agency (Japan) 
Katsuhiro Nakagawa, National Institute of Information and

Communications Technology (Japan)

Haruhisa Shimoda, Tokai University (Japan)

Kohei Mizutani, National Institute of Information and

Communications Technology (Japan)

Wonkook Kim, Korea Institute of Ocean Science and Technology (Republic of Korea)

YoungJe Park, Korea Institute of Ocean Science and Technology (Republic of Korea)

Jhoon Kim, Yonsei University (Republic of Korea)

Xianqiang He, Second Institute of Oceanography, State Oceanic Administration (China)

Shunling Liang, Beijing Normal University (China) 


\title{
Conference Committee
}

\author{
Conference Chairs
}

Eastwood Im, Jet Propulsion Laboratory (United States)

Song Yang, U.S. Naval Research Laboratory (United States)

\section{Conference Program Committee}

Kinji Furukawa, Japan Aerospace Exploration Agency (Japan)

Parminder Ghuman, NASA Goddard Space Flight Center (United States)

Ziad S. Haddad, Jet Propulsion Laboratory (United States)

Kyung-Soo Han, Pukyong National University (Korea, Republic of)

Jianping Huang, Lanzhou University (China)

Toshio Iguchi, National Institute of Information and Communications Technology (Japan)

Chandra Mohan Kishtawal, Indian Space Research Organization (India)

Pavlos Kollias, Stony Brook University (United States)

Raj Kumar, Indian Space Research Organisation (India)

Chian-Yi Liu, National Central University (Taiwan)

Byung-Ju Sohn, Seoul National University (Korea, Republic of)

Graeme L. Stephens, Jet Propulsion Laboratory (United States)

Pao-Kuan Wang, Academia Sinica (Taiwan)

Peng Zhang, National Satellite Meteorological Center (China)

Session Chairs

1 Remote Sensing of Clouds and Precipitation

Song Yang, U.S. Naval Research Laboratory (United States)

2 Remote Sensing of Aerosols and Dust

Parminder Ghuman, NASA Goddard Space Flight Center (United States)

3 Emerging Technologies for Atmospheric Remote Sensing I

Eastwood Im, Jet Propulsion Laboratory (United States)

Kinji Furukawa, Japan Aerospace Exploration Agency (Japan)

4 Remote Sensing of Cyclones and Severe Storms

Toshio Iguchi, National Institute of Information and Communications

Technology (Japan)

William J. Blackwell, MIT Lincoln Laboratory (United States) 
5 Emerging Technologies for Atmospheric Remote Sensing II

Parminder Ghuman, NASA Goddard Space Flight Center (United States)

Pao-Kuan Wang, Academia Sinica (Taiwan)

6 Modeling and Impact Studies of Atmospheric Observations

Pavlos Kollias, Stony Brook University (United States)

Yuzhi Liu, Lanzhou University (China)

7 Algorithm and Validation of Aerosols, Clouds, Convection, and Precipitation

Ziad S. Haddad, Jet Propulsion Laboratory (United States)

Yuzhi Liu, Lanzhou University (China)

8 Remote Sensing of Extreme Weather and Events

Parminder Ghuman, NASA Goddard Space Flight Center (United States)

Pao-Kuan Wang, Academia Sinica (Taiwan)

9 Remote Sensing of Atmospheric Chemistry and Greenhouse Gases

Pavlos Kollias, Stony Brook University (United States)

10 Regional Studies of Aerosols, Clouds, Convection, and Precipitation

Pavlos Kollias, Stony Brook University (United States) 